\title{
Nature of the Determinant Responsible for the Adhesion of Lactobacilli to Chicken Crop Epithelial Cells
}

\author{
By R. FULLER \\ National Institute for Research in Dairying, Shinfield, Reading RG2 $9 A T$
}

(Received 25 July I974; revised 17 October 1974)

SUMMARY

Using an in vitro method, some factors affecting the attachment of a strain of lactobacillus to chicken crop epithelial cells have been studied. Time of contact beyond Io min, $\mathrm{pH}$ value, age or growth temperature of the bacterial culture, or nature of the energy source in the growth medium had little or no effect on attachment. Heating to $100{ }^{\circ} \mathrm{C}$ for Io min, or treatment with EDTA or surface active compounds was also without effect. Treatment with sodium periodate markedly decreased adhesion, proteolytic enzymes had a smaller effect but wheat germ lipase was completely inactive. The pronounced inhibition of adhesion by periodate suggested the involvement of carbohydrate. However, enzymes known to attack carbohydrate substrates were inactive in reducing adhesion. Concanavalin A, which binds specifically to certain sugar residues, reduced attachment. It is suggested that these concanavalin A receptors on the lactobacillus are responsible for its attachment to crop epithelial cells.

\section{INTRODUCTION}

In recent years there has been increasing interest in the phenomenon of microbial attachment to surfaces as an ecological determinant. In particular the work of Gibbons \& Van Houte (I97I) has shown the central role that adherence to epithelial cells plays in colonization of the buccal mucosa. Another example is provided by the population of lactobacilli which attaches to the epithelial lining of the chicken crop (Fuller, 1973). This ability to attach is restricted to certain biotypes isolated from birds; lactobacilli from other sources fail to adhere (Fuller \& Turvey, I97I). It can reasonably be assumed that as with oral streptococci (Ellen \& Gibbons, 1974), this attachment depends on specific adhesion determinants on the surface of the bacterium. This paper reports some studies on the nature of the surface component which determines whether a particular strain of lactobacillus will adhere to crop epithelium.

\section{METHODS}

Bacterial strains. Lactobacillus strain 59, which attaches to chicken crop epithelium, was used for most of the work. It was isolated from the crop wall of a 3-month-old chicken and belongs to physiological group B as described by Fuller (1973). Strains 2 and 6 also adhere to crop epithelium and belong to physiological groups $\mathrm{G}$ and $\mathrm{A}$, respectively. The three nonadhering organisms were supplied by Dr M. E. Sharpe of this Institute. They were Lactobacillus acidophilus NCTCI 723 isolated from rat faeces, L. salivarius ATCCI I74I from human saliva and $L$. fermenti ATCC9338 from an unknown source.

Media. For experiments on the effect of carbohydrate source on adhesion, a basal medium 
was used with the following composition $(\%, w / v)$ : peptone, 15 ; Yeastrel, 6; Tween 80, I ; $\mathrm{pH} 6.4$. Carbohydrate was added at the rate of $0.5 \%(\mathrm{w} / \mathrm{v})$. For all other purposes MRS medium (de Man, Rogosa \& Sharpe, 1960) was used.

Test for adhesion of Lactobacillus 59 to crop epithelial cells in vitro. An overnight culture of strain 59 in MRS was centrifuged and the bacteria resuspended in phosphate buffered saline (PBS) at pH 7.3 (Cruikshank, 1972). Crop epithelial cells were collected from starved chickens by scraping the crop wall with the edge of a glass slide and suspending the scrapings in PBS. The two suspensions were mixed to give a final ratio of 50 bacteria to one epithelial cell. After rotating ( $\mathrm{I} 6 \mathrm{rev} . / \mathrm{min}$ ) at $37^{\circ} \mathrm{C}$ for $30 \mathrm{~min}$, a sample was withdrawn and examined under phase-contrast illumination and the number of bacteria attached to each of ten epithelial cells was counted.

Effect of varying test conditions and culture conditions on adhesion. The effects of varying the time of contact, the temperature at which the test was conducted and the $\mathrm{pH}$ of the suspending medium were examined using the test described above. Acetate buffer ( $0 \cdot \mathrm{I} M)$ was used for $\mathrm{pH}$ values of 4 and 5 , and phosphate buffer (O.I M) for $\mathrm{pH}$ values of 6,7 and 8 .

The adhesion index was calculated as the number of bacteria attached to each epithelial cell, expressed as a percentage of the highest number recorded for any treatment in the group in which that variable was examined.

Characterization of adhesion determinant. The nature of the adhesion determinant on the bacterium was studied by pre-treating strain 59 with substances which specifically degrade or block sites on the bacterial surface. The materials and conditions under which they were tested were as follows: EDTA $(\mathrm{BDH}), 4.5 \%(\mathrm{w} / \mathrm{v})$ in distilled water, mixed with epithelial cells also suspended in $4.5 \%$ EDTA and tested immediately; chicken bile, freshly collected and used undiluted; Lissapol (ICI), $0 \cdot \mathrm{I} \%(\mathrm{v} / \mathrm{v})$ in distilled water; dodecyl benzene sulphonic acid (BDH), $0.1 \%(w / v)$ in distilled water; lysolecithin (Koch-Light Laboratories Ltd, Colnbrook, Buckinghamshire) in $0 . \mathrm{I}$ M-phosphate buffer at $\mathrm{pH} 7.5$; sodium periodate (BDH), ro $\mathrm{mg} / \mathrm{ml}$ in PBS; trypsin, $2 \mathrm{mg} / \mathrm{ml}$ in $0 . \mathrm{I} \mathrm{M}$-phosphate buffer at $\mathrm{pH} 8.0$; wheat germ lipase, $2 \mathrm{mg} / \mathrm{ml}$ in $0 . \mathrm{I} \mathrm{M}$-acetate buffer at $\mathrm{pH} 5.0$; protease, $0.2 \mathrm{mg} / \mathrm{ml}$ in $0 . \mathrm{I} \mathrm{M}$-phosphate buffer at $\mathrm{pH} 7.5$; pepsin, $0.2 \mathrm{mg} / \mathrm{ml}$ in citrate $(0.0446 \mathrm{M})$ phosphate $(0.0108 \mathrm{M})$ buffer at $\mathrm{pH} 2.6$; $\beta$-glucuronidase, 1390 units $/ \mathrm{ml}$ in $0^{\circ} \mathrm{I}$ M-acetate buffer at $\mathrm{pH} 5.0 ; \alpha$-glucosidase, $3 \mathrm{mg} / \mathrm{ml}$ in $0 . \mathrm{I} \mathrm{M}$-phosphate buffer at $\mathrm{pH} 6.8 ; \beta$-glucosidase, $\mathrm{IO} \mathrm{mg} / \mathrm{ml}$ in $0 . \mathrm{I}$ M-acetate buffer at $\mathrm{pH} 5^{\circ} \mathrm{O}$; neuraminidase, $5 \mathrm{mg} / \mathrm{ml}$ in calcium acetate saline (Ada \& Stone, 1950) at pH 6.2; $\alpha$-amylase, Io $\mathrm{mg} / \mathrm{ml}$ in $0 . \mathrm{I} \mathrm{M}$-phosphate buffer at $\mathrm{pH} 6.9 ;$ lysozyme, $0.2 \mathrm{mg} / \mathrm{ml}$ in 0.1 M-phosphate buffer at $\mathrm{pH} 6.2$; dextranase, $0.4 \mathrm{mg} / \mathrm{ml}$ in 0.1 M-acetate buffer at $\mathrm{pH} 5.0$; hyaluronidase, Io units $/ \mathrm{ml}$ in $0 . \mathrm{I} \mathrm{M}$-acetate buffer at $\mathrm{pH} 5.0$. Unless otherwise stated, all reagents were obtained from Sigma. All reagents were in contact with the bacteria for $4 \mathrm{~h}$ at room temperature and, except for EDTA, at the end of the contact time the bacteria were washed twice in PBS and then tested in the standard attachment test. Control treatments in which the bacteria were in contact with the appropriate suspending fluid were always included.The adhesion index was calculated as the number of bacteria attached per epithelial cell, expressed as a percentage of the number attached in the control. Positive results (i.e. those showing more than $50 \%$ reduction of adhesion) were repeated at least once.

Preparation of monovalent concanavalin A. Concanavalin A (conA), from Sigma, was converted to the monovalent form by digestion with chymotrypsin (Sigma) according to the method described by Steinberg \& Gepner (1973).

Carbohydrate analysis. The method of Dubois et al. (1956) was used and carbohydrate estimated by measuring the absorbance at $490 \mathrm{~nm}$.

Agglutination by concanavalin A. Agglutination of lactobacilli by conA was examined by 
Table I. Effect of various test conditions on adhesion of lactobacillus strain 59 to crop epithelial cells

$\begin{array}{lccc} & \begin{array}{c}\text { No. of } \\ \text { experiments }\end{array} & \begin{array}{c}\text { Mean no. } \\ \text { bacterial } \\ \text { cell }\end{array} & \begin{array}{c}\text { Adhesion } \\ \text { index }\end{array} \\ \begin{array}{c}\text { Time of contact with } \\ \text { epithelial cells (min) }\end{array} & & & \\ \text { I0 } & 2 & 25 & 93 \\ 20 & 2 & 24 & 89 \\ 30 & 2 & 26 & 96 \\ 60 & 2 & 27 & 100 \\ \text { Temperature }\left({ }^{\circ} \text { C) }\right. & & & \\ 4 & 3 & 30 & 88 \\ 24 & 3 & 29 & 85 \\ 37 & 3 & 34 & 100 \\ 45 & 3 & 34 & 100 \\ \text { pH } & & & \\ 4 & & 42 & 100 \\ 5 & \text { I } & 40 & 96 \\ 6 & \text { I } & 40 & 96 \\ 7 & \text { I } & 36 & 86 \\ 8 & \text { I } & 37 & 88\end{array}$

Table_2. Effect of culture conditions on adhesion of lactobacillus strain 59 to crop epithelial cells

$\begin{array}{lccc}\text { Age of culture (h) } & \begin{array}{c}\text { No. of } \\ \text { experiments }\end{array} & \begin{array}{c}\text { Mean no. } \\ \text { bacterial } \\ \text { cell }\end{array} & \begin{array}{c}\text { Adhesion } \\ \text { index }\end{array} \\ \quad 2 & 2 & 32 & 92 \\ 6 & 2 & 35 & 100 \\ \text { I2 } & 2 & 35 & 100 \\ 24 & 2 & 31 & 89 \\ \text { Temperature of bacterial growth }\left({ }^{\circ} \mathrm{C}\right) & & & \\ 37 & 2 & 37 & 100 \\ 45 & 2 & 33 & 89 \\ \text { Carbon source in growth medium } & & & \\ \quad \text { Trehalose } & \text { I } & 37 & 100 \\ \text { Sucrose } & \text { I } & 35 & 95 \\ \text { Glucose } & \text { I } & 34 & 92 \\ \text { Raffinose } & \text { I } & 28 & 76 \\ \text { Mannitol } & \text { I } & 22 & 60\end{array}$

suspending bacteria in $0.1 \mathrm{M}$-phosphate buffer $\mathrm{pH} 7 \cdot 5$ to give a concentration of about $10^{8} /$ $\mathrm{ml}$. One volume of this suspension was added to an equal volume of conA solution $(0 \cdot 2 \mathrm{mg} /$ $\mathrm{ml}$ in $\mathrm{O} . \mathrm{I} \mathrm{M}$-phosphate buffer $\mathrm{pH} 7.5$ ) and left at room temperature. Agglutination was detected microscopically within $4 \mathrm{~h}$ and visible agglutination developed overnight.

\section{RESULTS}

\section{Effect of test conditions on adhesion}

None of the parameters examined had any marked effect on the adhesion of the lactobacillus to crop epithelial cells (Table I). Attachment was rapid and was not increased by incubation beyond ro min contact time. Temperatures between 4 and $45{ }^{\circ} \mathrm{C}$ and $\mathrm{pH}$ values between 4 and 8 were also without effect. Attachment at a temperature of $4^{\circ} \mathrm{C}$ or at $\mathrm{pH} 4$ indicates that active metabolism of the bacterium is not a prerequisite for adhesion. 
Table 3. Effect of heat, EDTA and surface active compounds on adhesion of lactobacillus strain 59 to crop epithelial cells

$\begin{array}{lccc}\text { No. of } & \begin{array}{c}\text { Mean no. } \\ \text { bacterial } \\ \text { cell }\end{array} & \begin{array}{c}\text { Adhesion } \\ \text { index }\end{array} \\ \text { Unheated (control) } & 3 & 33 & 100 \\ \text { I00 }^{\circ} \mathrm{C} \text { for } 5 \mathrm{~min} & 3 & 27 & 82 \\ \text { I00 }^{\circ} \mathrm{C} \text { for } 10 \mathrm{~min} & 3 & 24 & 73 \\ \text { EDTA } & \text { I } & 30 & 91 \\ \text { Chicken bile } & \text { I } & 28 & \text { I02 } \\ \text { Lissapol } & \text { I } & 26 & 96 \\ \text { Dodecyl benzene sulphonate } & \text { I } & 22 & 82 \\ \text { Lysolecithin } & \text { I } & 30 & 94\end{array}$

Table 4. Effect of periodate, enzymes and conA on adhesion of lactobacillus strain 59-to crop epithelial cells

$\begin{array}{lccc}\text { Sodium periodate } & \begin{array}{c}\text { No. of } \\ \text { experiments }\end{array} & \begin{array}{c}\text { Mean no. } \\ \text { bacteria/ } \\ \text { cell }\end{array} & \begin{array}{c}\text { Adhesion } \\ \text { index }\end{array} \\ \text { Lipase } & 3 & 2 & 6 \\ \text { Trypsin } & 3 & 31 & 99 \\ \text { Protease } & 3 & 22 & 78 \\ \text { Pepsin } & 2 & 12 & 38 \\ \beta \text {-Glucuronidase } & 2 & 4 & 14 \\ \text {-Glucosidase } & 1 & 34 & 113 \\ \beta \text {-Glucosidase } & \text { I } & 21 & 92 \\ \text { Neuraminidase } & \text { I } & 43 & \text { I19 } \\ \alpha \text {-Amylase } & \text { I } & 34 & 103 \\ \text { Lysozyme } & \text { I } & 34 & 95 \\ \text { Dextranase } & \text { I } & 31 & 94 \\ \text { Hyaluronidase } & 2 & 26 & 87 \\ \text { ConA } & 3 & 25 & 83 \\ & & 1 \text { I } & 38\end{array}$

Effect of culture conditions on adhesion

The effect of manipulating the conditions under which the culture was grown was examined (Table 2). The age of the cultures tested ranged from 3 to $24 \mathrm{~h}$, which included exponentialphase organisms ( 3 and $6 \mathrm{~h}$ ) and stationary-phase organisms (I 2 and $24 \mathrm{~h}$ ). All adhered equally well. Although growth occurred in MRS medium at 24 and $30^{\circ} \mathrm{C}$ there was strong autoagglutination which made quantitative assessment of adhesion impossible. Growth at 37 and $45^{\circ} \mathrm{C}$ was normal but there was no marked difference in adhesion. There was no growth at $50^{\circ} \mathrm{C}$. The effect of growing the lactobacillus in media containing different carbon compounds as sole energy source was studied. Five energy sources which the lactobacillus could utilize were tested but with the possible exception of mannitol little difference in adhesion was detected.

\section{Characterization of adhesion determinant}

The adhesion determinant on the lactobacillus was heat stable, there being little reduction in adhesion even after heating to $100^{\circ} \mathrm{C}$ for $10 \mathrm{~min}$. EDTA and the surface active compounds tested also had no effect on adhesion (Table 3). In an attempt to characterize the determinant on the bacterium, strain 59 was treated with sodium periodate, trypsin or wheat germ lipase (Table 4). The inhibition obtained with periodate strongly suggested the involvement of carbohydrate. Efforts to further identify this carbohydrate centred on the use of 
enzymes known to attack carbohydrate substrates. However, none of those shown in Table 4 had any marked effect.

The inhibition with trypsin, though small, was reproducible, and protease and pepsin were found to be even more active. Concanavalin A agglutinated three strains of lactobacilli which adhered to crop epithelial cells in vitro, but failed to agglutinate three non-adhering strains. This was further investigated by attempting to prevent adhesion by blocking the sites on the bacterial surface with conA. Unfortunately, this agglutinated the bacteria so that quantitative assessment of adhesion was impossible. Monovalent conA was therefore made by chymotrypsin digestion. When this was used to pretreat the bacteria they lost their conA agglutinability, showing that the monovalent conA had saturated the binding sites. Treatment of lactobacilli with monovalent conA markedly reduced adhesion.

The identification of the adhesion determinant as a conA receptor was at odds with the finding that proteolytic enzymes decreased attachment. However, cultures released carbohydrate during pepsin treatment. The increase in $490 \mathrm{~nm}$-absorbing material on pepsin digestion ranged from 115 to $213 \%$ of that released by organisms suspended in buffer. Moreover, conA precipitated the carbohydrate released, showing free conA receptors to be present.

\section{DISCUSSION}

The chicken crop contains a characteristic microflora consisting predominantly of lactobacilli with smaller numbers of coliforms and streptococci (Smith, I965). If the lactobacilli are eliminated by penicillin there is a great increase in the numbers of coliforms in the crop (Fuller, I973). Thus the maintenance of the lactobacilli in this dominant position is essential for the development of a balanced crop microflora. The presence of large numbers of lactobacilli in the crop is ensured by the ability of certain biotypes to attach to the crop wall. The determinants involved in this adhesion are carbohydrate, as shown by their susceptibility to oxidation with sodium periodate and their binding to conA.

Thin sections of lactobacilli attached to crop wall when stained with ruthenium red showed that carbohydrate is organized as a layer outside the wall and has thin filaments extending from it to the surface of the epithelium. The primary site of adhesion is at the point where the ruthenium red-stained layer makes contact with the epithelium. The filaments are not essential for adhesion, because stationary-phase organisms do not possess them and yet still attach. The filaments may reinforce the primary attachment (Brooker \& Fuller, 1975). Staining of thin sections with a conA-peroxidase conjugate has confirmed the existence of conA binding sites on the surface of the lactobacillus (B. E. Brooker and R. Fuller, unpublished data).

The inhibition of adhesion by proteolytic enzymes as well as by periodate may point to glycoprotein involvement or may be due to the hydrolysis of a layer of protein under the carbohydrate which frees the latter from the wall. The release of carbohydrate and conA binding material after proteolysis shows that protein per se is not the determinant. This susceptibility to more than one enzyme with totally different specificities is not unusual in work of this kind. For example, the adhesion determinants on Streptococcus pyogenes are destroyed by both trypsin and wheat germ lipase (Ellen \& Gibbons, I974) and in the case of zoospores of Enteromorpha intestinalis adhesion was weakened by proteolytic enzymes and $\alpha$-amylase (Christie, Evans \& Shaw, 1970).

Although squamous epithelium lines both the chicken crop and the human mouth, lactobacilli occupy only a subdominant niche in the latter site. Moreover, in the human mouth, streptococci will attach to the vestibular mucosa (Van Houte, Gibbons \& Pulkkinen, 1972), whereas they are never seen attaching to crop epithelium. This suggests that even the same 
type of epithelium from different hosts may possess different receptors. This view is supported by the finding that Streptococcus salivarius strains which attach to human cheek epithelium do not adhere to crop epithelium (Fuller, 1973). Within the same host also there are different receptors on different epithelia. Thus in the chicken, although lactobacilli are present throughout the gut, they adhere only in the crop where squamous epithelium is present. Presumably the small intestine flora merely reflects the crop flora whereas in the caecum, where high counts are found, there is stasis which allows time for multiplication and attachment is less important.

Evidently the different bacteria have different adhesion determinants. Many different mechanisms of attachment have been described, varying from $\mathbf{M - p r o t e i n ~ f o r ~ a t t a c h m e n t ~ o f ~}$ S. pyogenes to tonsils (Ellen \& Gibbons, 1972) to involvement of fimbriae for gonococci in the urethra (Punsalong \& Sawyer, 1973) and lipid for mycoplasmas and tracheal cells (Sobeslavsky, Prescott \& Chanock, 1968). The evidence presented here shows yet another type of determinant, which is a carbohydrate capable of binding conA. The specificity of con A for glucose, mannose, fructose or arabinose moieties with the $\alpha$-anomeric configuration (Sharon \& Lis, 1972) indicates the existence of one or more of such sites on the surface of these lactobacilli and implies their involvement in adhesion.

I gratefully acknowledge the excellent technical assistance of Mr J. G. Smith, Mrs S. O. Porcas and Miss E. Woodcock.

\section{REFERENCES}

ADA, G. L. \& STONE, J. D. (I950). Electrophoretic studies of virus-red cell interaction: mobility gradient of cells treated with viruses of the influenza group and the receptor destroying enzyme of Vibrio cholerae. British Journal of Experimental Pathology 31, 263-274.

Brooker, B. E. \& Fuller, R. (I975). Adhesion of lactobacilli to the chicken crop epithelium. Journal of Ultrastructure Research 49 (in the Press).

Christie, A. O., Evans, L. V. \& Shaw, M. (1970). Studies on the ship-fouling alga Enteromorpha. II. The effect of certain enzymes on the adhesion of zoospores. Annals of Botany 34, 467-482.

Cruikshank, R. (1972). Medical Microbiology, i I th edn. London: Churchill Livingstone.

Dubois, M., Gillies, K. A., Hamilton, J. K., Rebers, P. A. \& Smith, F. (1956). Colorimetric method for determination of sugars and related substances. Analytical Chemistry 28, 350-356.

Ellen, R. P. \& GibBons, R. J. (I972). M-protein associated adherence of Streptococcus pyogenes to epithelial surfaces: prerequisite for virulence. Infection and Immunity $5,826-830$.

Ellen, R. P. \& Gibbons, R. J. (I974). Parameters affecting the adherence and tissue tropisms of Streptococcus pyogenes. Infection and Immunity $9,85-9 \mathrm{I}$.

Fuller, R. (1973). Ecological studies on the lactobacillus flora associated with the crop epithelium of the fowl. Journal of Applied Bacteriology 36, 131-1 39.

Fuller, R. \& Turvey, A. (I97I). Bacteria associated with the intestinal wall of the fowl (Gallus domesticus). Journal of Applied Bacteriology 34, 617-622.

Gibbons, R. J. \& VAN Houte, J. (197I). Selective bacterial adherence to oral epithelial surfaces and its role as an ecological determinant. Infection and Immunity 3, 567-573.

De Man, J. C., Rogosa, M. \& Sharpe, M. E. (1960). A medium for the cultivation of lactobacilli. Journal of Applied Bacteriology 23, 130-135.

Punsalong, A. P. \& SAWYeR, W. D. (I973). Role of pili in the virulence of Neisseria gonorrhoeae. Infection and Immunity 8, 255-263.

SHARON, N. \& LIS, H. (1972). Lectins: cell-agglutinating and sugar-specific proteins. Science $\mathbf{1 7 7}, 949-959$.

SMITH, H. W. (1965). Observations on the flora of the alimentary tract of animals and factors affecting its composition. Journal of Pathology and Bacteriology 89, 95-122.

Sobeslavsky, O., Prescott, B. \& Chanock, R. M. (1968). Adsorption of Mycoplasma pneumoniae to neuraminic acid receptors of various cells and possible role in virulence. Journal of Bacteriology $\mathbf{9 6}$, $695-705$.

Steinberg, M. S. \& GePner, I. A. (I973). Are concanavalin A receptor sites mediators of cell-cell adhesion? Nature, New Biology 24I, 249-25I.

Van Houte, J., Gibbons, R. J. \& Pulkkinen, A. J. (I972). Ecology of human oral lactobacilli. Infection and Immunity 6, 723-729. 